\title{
Shrimp Cultivation with Water Salinity in Bangladesh: The Implications of an Ecological Model
}

\author{
Md. Mizanur Rahman ${ }^{1}$, Vincentas Rolandas Giedraitis ${ }^{2, *}$, Leslie Sue Lieberman ${ }^{3}$, \\ Mrs. Tahmina Akhtar ${ }^{4}$, aida Taminskiené ${ }^{5}$ \\ ${ }^{1}$ Department of Social Work, Shahjalal University of Science and Technology, Bangladesh \\ ${ }^{2}$ Faculty of Economics, Vilnius University, Lithuania \\ ${ }^{3}$ Department of Anthropology, University of Central Florida, Orlando, USA \\ ${ }^{4}$ Institute of Social Work and Research, Dhaka University, Bangladesh \\ ${ }^{5}$ Institute of Public Health, Faculty of Medicine, LT-03101, Vilnius University, Lithuania \\ *Corresponding Author: vincas.giedraitis@ef.vu.lt
}

Copyright (C) 2013 Horizon Research Publishing All rights reserved.

\begin{abstract}
Despite unplanned and haphazard expansion of shrimp cultivation that immensely affects on the coastal regions of Bangladesh, the exploration of its adverse effects has not received significant attention from the researcher community yet. There were few researches and studies in Bangladesh conducted to elicit the colossal effects of shrimp production at different times that did not particularize its focus on proposing an ecological design of shrimp production. In order to elicit the concomitant impacts and propose an ecological model of shrimp cultivation based on secondary data, the present study was conducted by applying 'Systematic Review and Content Analysis' as research method. The study findings manifest that the continuous and unregulated shrimp farming has immense impacts on human health, ecology, environment and sustainability though few of them directly benefit the shrimp farmers and the people who live around them. The extensive farming systems negatively expedite the processes: infringement of mangroves, intrusion of salinity, degradation of land, de-stabilization of coastal ecosystems. The major socio-economic effects challenge the patterns of livelihood pattern, displacement of family and social structure, internal migration, and livestock. The coastal regions suffer from environmental degradation due to increased salinity of soil, canals and ponds within dams, reduction in grazing field and livestock, changes in the cropping calendar and its pattern, bio-diversity. Ecological aspects and sustainability are also overlooked during the shrimp cultivation. In conclusion, proper implementation of the resilient strategies designed in an ecological model can minimize the adverse effects on the coastal dwellers and local environment, and improve the unplanned shrimp cultivation process in similar areas of Bangladesh.
\end{abstract}

Keywords Shrimp Cultivation/Farming/Industry, Water Salinity, Impact/Effect, Public Health, Ecology, Biodiversity, Environment, Sustainability, Ecological Model

\section{Introduction}

Shrimp production in a controlled and enclosed water body is described as Shrimp Cultivation. Both saline and fresh water can be used for this cultivation. Shrimp are the swimming crustaceans that inhabit the warm marine waters of the tropics and subtropics [1]. Production of farmed shrimp has been growing at the phenomenal annual rate of $20 \%$ - $30 \%$ since 1990 [2]. Initially, shrimp farming was introduced in the coastal areas particularly in the Southwestern part and Cox's Bazar district. Currently, shrimp fishes are cultivated throughout coastal region and Bangladesh produces more than $2.5 \%$ of the global production of shrimp and becomes the 7th largest exporter of shrimp to the Japanese and USA markets [3]. Fisheries are respected because they are one of the major sources of livelihood in Bangladesh where almost 2.2 million of people are directly involved in this sector and another 11 million indirectly. Bangladesh has a total of 25 million hectors of water resources where a total of 129.8 million pounds of fish and shrimp were produced in 2009-2010. Fisheries contribute to $5.5 \%$ of the national GDP and $7 \%$ of total export income and are considered the 3rd major export commodity in Bangladesh. Of the fishery commodities exporting shrimps like Black Tiger (Penaeus Monodon) and fresh water scampi (Macrobrachium Rosenbergii) bring the most of foreign currency in this sector [3]. The economic incentives encourage farmers to bring thousand of acres of lands under shrimp farms most of which are unplanned and haphazardly expanded, and also to use saline water carried by canals and rivers from the Bay of Bengal, employ traditional farming systems in all sub-sectors of the fishing and its processing systems, use vivid chemicals sensitive to the overall environment [4]. All steps employed to the process of unplanned shrimp cultivation diversely affect on the soil and agriculture yields, ecology, biodiversity and sustainability in the coastal regions of Bangladesh. Ancillary activities of shrimp farmers regarding shrimp production 
need to reevaluate for avoiding the disrupting consequences on community/lower class and on their healthy status. Above all, to minimize the harmful effects, strategies that are conducive to local ecology, environment and its sustainability should be taken by the government of Bangladesh and its local bodies.

\section{Methods and Materials}

The main purpose of this research is to assess the various impacts of unplanned shrimp cultivation with water salinity on the local peoples' lives, livelihood and health, livestock, ecology and ecosystems, bio-diversity, environment and sustainability as well as to propose an ecological model of shrimp cultivation for minimizing its worse impact on the coastal regions in Bangladesh. The present study has been accomplished based on secondary data from the studies already conducted on the effects of shrimp farming with water salinity in the coastal areas of Bangladesh. 'Systematic Review' and 'Content Analysis' have been applied as methods of the study. 'Inclusion Criteria' of the systematic review method has been followed as technique of identifying the key materials for review.' The procedures of content analysis such as selection of useful contents, identification of sources, coding, unit of analysis, and strength of content intensity have been adopted to interpret the relevant findings in the study. Few key words: shrimp farms with water salinity, brackish water shrimp, effects of shrimp cultivation, sustainable shrimp farming, economic evaluation of shrimp farms (Gher) and shrimp farming systems with water salinity been used as to searching materials from websites, different books, articles, research reports, and print medias. Statistical records, survey archives and written documents of document study are used to collect secondary data from the materials selected for the study.

\section{Findings}

\subsection{The Existing Situation of Shrimp Cultivation with Water Salinity in Bangladesh}

Bangladesh is a deltaic country with total area of 147,570 sq. $\mathrm{km}$. The major part $(80 \%)$ of the country consists of alluvial sediments and of which the coastal region covers almost 29,000 sq. km or about $20 \%$ of the country which also cover more than $30 \%$ of the cultivable lands. The areas marked by blue color in the Figure-1 are used for shrimp cultivation and estimated about $53 \%$ of the coastal areas affected by salinity because of shrimp cultivation. These areas are generally low lying, barely one meter above mean sea level, and below high tide level conducive to shrimp fishes production. The Sundarban forest discards about 3.5 million tons of detritus per year [5] that is carried to the farthest corners of the land by the tides. When decomposed in the water it deposits in the highly coastal wetlands and thereafter transforms into nutritious organic food for all types of aquatic lives. When it is deposited along with the silt, the land becomes natural subsidence of the loose delta soil, which is common to all similar areas vegetation and wetlands throughout the world [1].

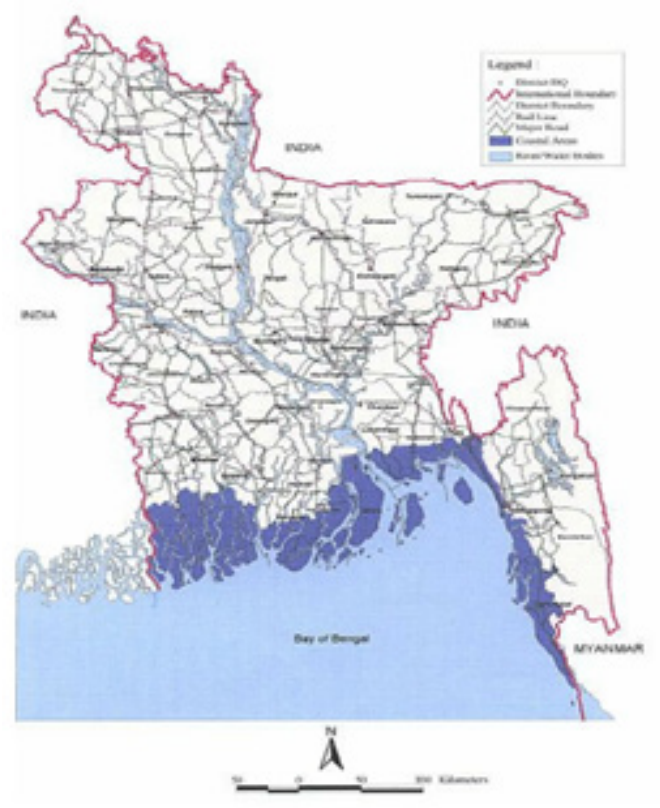

A

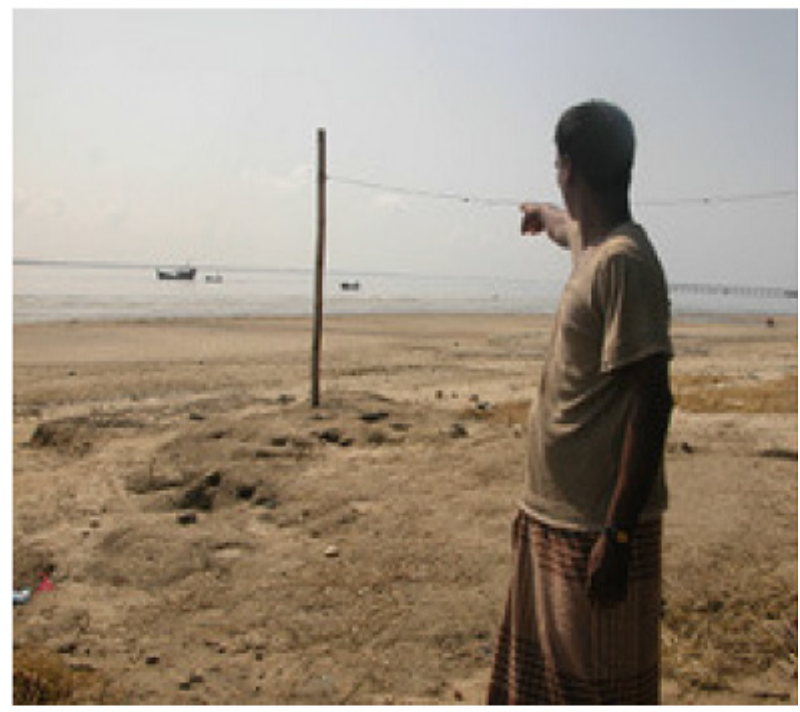

B

Figure 1. The Regions (A) and Effects (B) of Extensive Shrimp Farming in Bangladesh

\subsection{Aspects of Shrimp Cultivation}

Traditional 'Gher' aquaculture had been practiced in the coastal areas of Bangladesh to grow shrimp and other fishes long before the introduction of current shrimp culture practices [6]. In the early 1960s, the government constructed a large number of coastal embankments to protect agricultural land in the coastal areas from tidal waves and 
saline water intrusion. Since the 1970s, strong international market demand and high prices for shrimp product have encouraged farmers to recommence shrimp farming in polders within the embanked areas. Contrastingly, to cultivate rice was no longer financially viable because the polders had become waterlogged due to poor drainage. These two factors together provided a mechanism to the process of accelerated shrimp farming [7]. The government of Bangladesh acknowledged shrimp farming as an industry under the Second Five-Year Plan (1980-85) and adopted measures essential for increased shrimp production [8]. In 1979-80, slightly more than 20,000 hectors were under shrimp cultivation. According to an estimate by the Master Plan Organization [9], the total area under shrimp culture was expected to rise from 96,048 hectors in 1990 to 135,000 hectors in 2005. As of 1994, there were already about $130,000-138,000$ hectors of shrimp farms $[10,11]$ exceeding the projection for 2005 .

The leading shrimp farming areas of Bangladesh are the Bagerhat, Khulna and Satkhira Districts in the south-western region, Chittagong, Cox's Bazaar District in the south-eastern region. Satkhira District has the greatest potential for expansion of shrimp farming in the south-western region while potential for expansion in Cox's Bazaar District seems also very high [12]. The findings show that among several species available in the coastal regions, Penaeus Monodon locally known as Bagda Chingri indicated by Figure-2 (A) is the preferred species for brackish-water shrimp farming and attracts a very high price in international markets. Macrobrachium Rosenbergii (Galda Chingri) also accounts for $25 \%$ of the total production $[11,13]$.

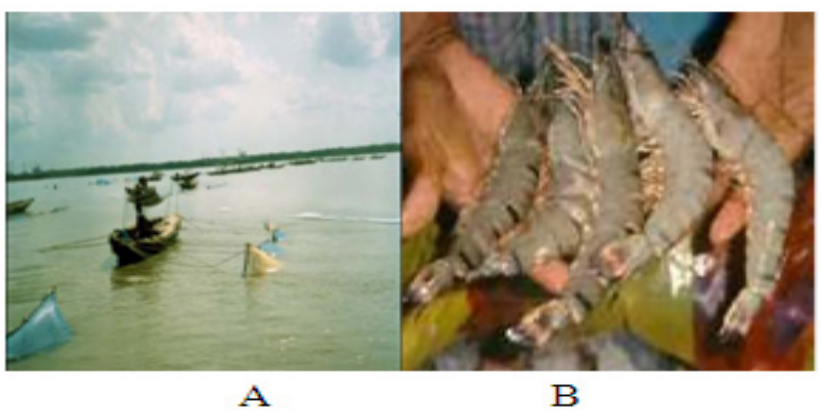

Figure2. Shrimp Catching Systems (A) and Picture of Shrimp Fish (B)

\subsection{Linking Components of Shrimp Industry}

As of Figure-3, the shrimp industry comprises four main sub-sectors: shrimp farms (Ghers), shrimp hatcheries, shrimp feed mills and shrimp processing plants [8]. Figure-3 adds that shrimp collectors, small-scale feed manufacturers and exporting agents also contribute to the existing systems. The success of the industry depends on the concomitant development of all sub-sectors and their ancillary activities. Its development, on the other hand, depends on the availability of modern technology, management and finance. The shrimp marketing system is also vital and comprises a complex chain of agents who are involved in the process from the farm gate to the processing plants. The processing plant sub-sector has ultimate command of the marketing system. This sector has also a vertical line of command, which in turn acts on international market signals [1].

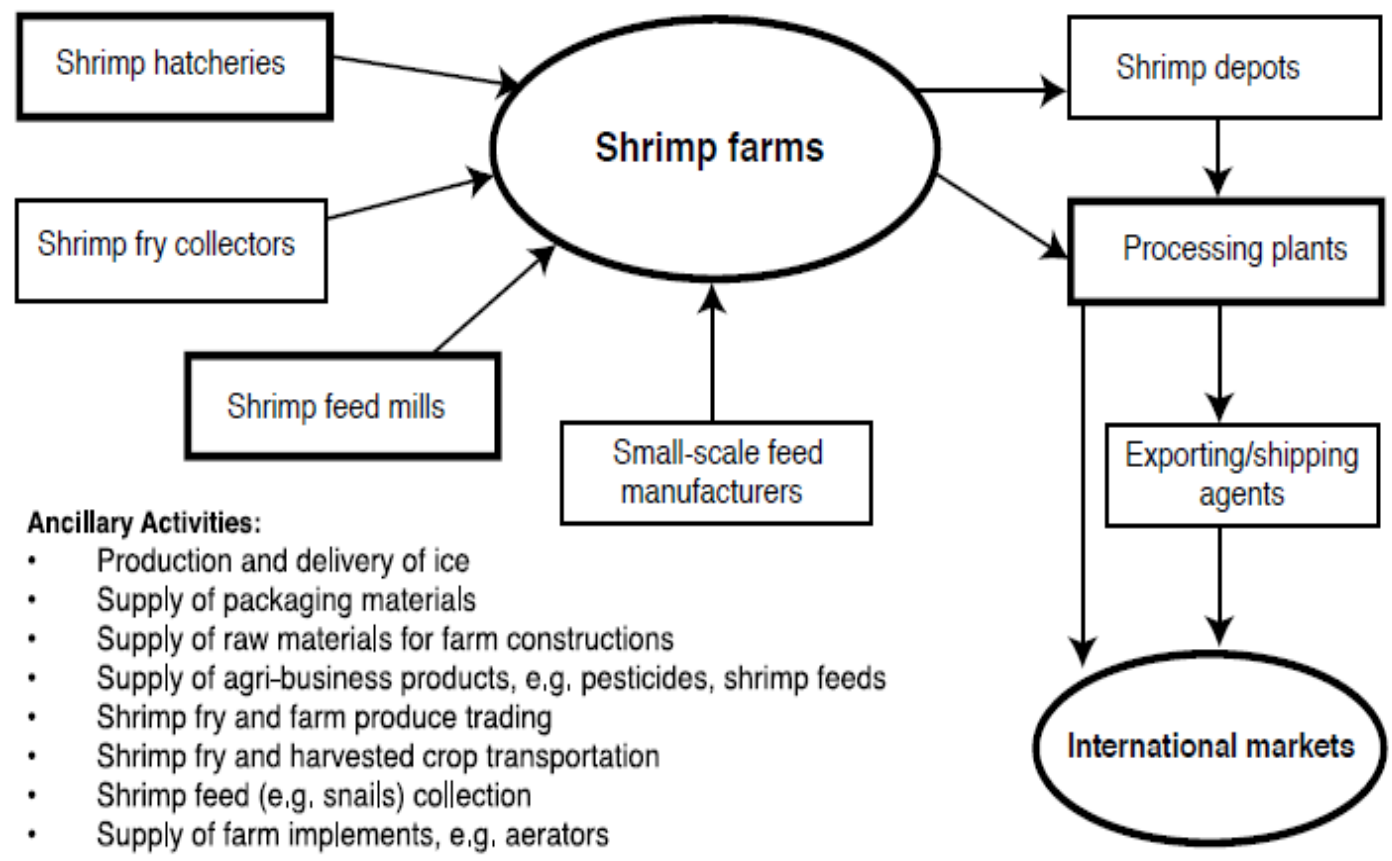

Source: (Alauddin and Hamid, no date)

Figure3. Shrimp Farming Systems and Linking Components of Shrimp Industry 


\subsection{Existing Shrimp Farming Systems and Technology}

The cropping pattern is for brackish-water shrimp in dry months (December-July). In some areas, shrimp farming is characterized by monoculture. In the south-eastern coastal areas, shrimps are grown from May to November and for the rest of the year, the land is used for salt production. In some parts of the south-eastern tidal area, rice alternates with shrimp and fish production [14]. On the other hand, there are only nine hatcheries in Bangladesh with limited capacity for shrimp fry production. Consequently, shrimp farmers are forced to rely on wild stocks or the importation of fry which lead to an increased cost of shrimp farming [15]. Shrimp fry obtained either from wild catch or commercial hatcheries are stocked in the nursery ponds before transferring to shrimp fields (Ghers). Intensive farming is practiced in small shrimp ponds with high stocking densities. This farming method entails heavy feeding, removal of farm waste, water exchange and installation of an aeration system $[5,16]$.

Attracted by prospects of high incomes and economic prosperity, the people who are socially and politically powerful use more land for shrimp cultivation. The land that was previously used for other crops (especially rice) or grazing land is brought under shrimp farm without justifying the feasibility of shrimp production and adverse effects of new shrimp farms on local peoples' life and livelihood, environment, ecosystems, and sustainability. The Figure-4 attests that these types of unplanned shrimp farms are run by different ownership systems that ultimately result to an uneven distribution of land ownerships, farming systems and its labour consumption. At present, the land holdings of marginal and small farmers have declined while large and very large farmers have acquired more land $[6,17]$.

\subsection{Socio-economic Circumstances}

Earlier, people of the area depended mostly upon the cultivation of food grains. Influence and status were achieved through the possession of land and crops. Shrimp cultivation sooner produced another moneyed class; influence and social power gradually transferred to others, and the basic social hierarchy broke down. This initially created a hazardous situation in the areas, as the inhabitants became hostages to the whims of these people. Gradually, the small landowners organized; protested against the newcomers and began individual and co-operative shrimp culture for their economic emancipation. Shrimp, thus, has replaced rice as the main crop; as traditional shrimp farming is easier and more profitable than rice growing. Poor womenfolk earn a considerable amount of money from fry collection, weeding out, de-heading and other related activities that help the local landless people alleviate poverty [18].

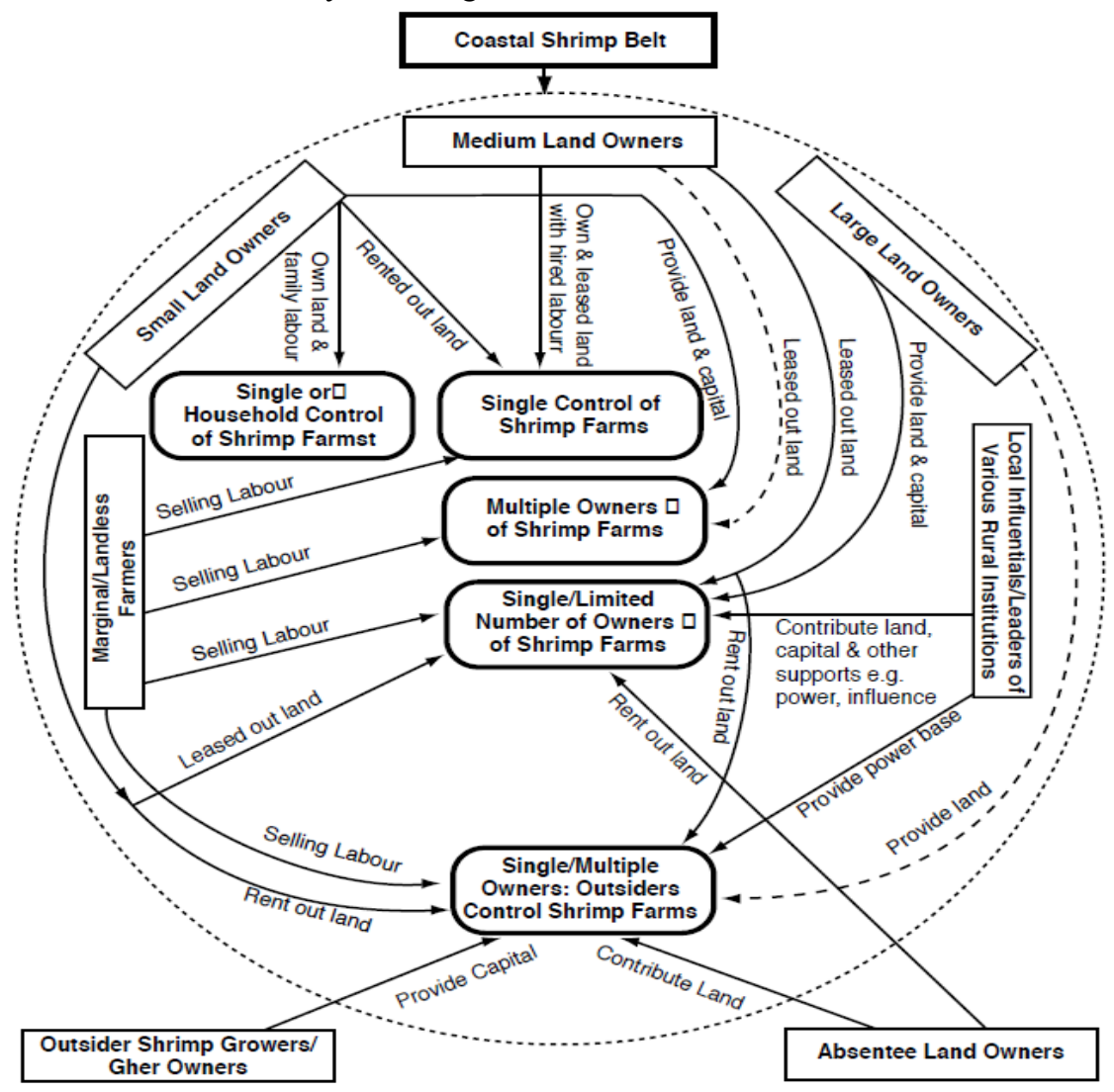

Source: (Alauddin and Hamid no date)

Figure 4. The Ownership System of Shrimp Farms 


\subsection{Salinity Built-up}

The main obstacle to intensification of crop production is seasonally high content of salts in the root zone of the soil. The salts enter inland through rivers and channels especially in dry season when the farmers cultivate their lands for shrimp production with water salinity that also cause an increase in salinity of the ground water and make it unsuitable for irrigation. Thus, shrimp cultivation plays a major role in increasing salinity particularly in the southern coastal regions. As estimated in Table-1, the severity of salinity problem increases with the aridness of the soil. Soil reaction values $(\mathrm{pH})$ in coastal regions range from 6.0-8.4. The organic matter content of the soils is also pretty low (1.0-1.5\%). Nutrient deficiencies of $\mathrm{N}$ and $\mathrm{P}$ are quite dominant in saline soils. Micronutrients such as $\mathrm{Cu}$ and $\mathrm{Zn}$ are widespread [1].

\subsection{Impacts of Shrimp Cultivation}

Over the last two decades, shrimp farming has emerged as a major industry in Bangladesh. As stated by Figure-5, the shrimp farming process starts from the input of saline water into fresh land previously used for agricultural production. The water is inundated and logged for a long time and shrimp fries are put into it. The shrimp prawns are grown up and take 3-6 months to be matured for catching. The saline water logging into fresh land degrades the soil quality of fresh lands that adversely affect on local vegetation, plants and trees, crops, fishes, livestock, environment, ecology, and population health and diseases patterns. These effects ultimately accelerate the process of changes in physical, aquatic and terrestrial environment, deforestation, biodiversity, ecosystems all of which change in climate and indoor environment of Bangladesh. All of these may have serious implications for sustainability as well.

Table 1. Agro-chemical characteristics of Soils in Coastal and Offshore Areas of Bangladesh

\begin{tabular}{|c|c|c|c|c|c|c|c|c|c|c|c|}
\hline District & $\mathrm{pH}$ & $\begin{array}{c}\mathrm{OM} \\
\%\end{array}$ & $\begin{array}{c}\text { Total N } \\
\%\end{array}$ & $\begin{array}{l}\text { CEC } \\
\text { m.e. } \%\end{array}$ & $\begin{array}{l}\mathrm{Na} \\
\text { m.e.\% }\end{array}$ & $\begin{array}{c}\mathrm{K} \\
\mathrm{m} . e . \%\end{array}$ & $\begin{array}{l}\mathrm{Ca} \\
\text { m.e. } \%\end{array}$ & $\begin{array}{c}\mathrm{Mg} \\
\text { m.e. } \%\end{array}$ & $\begin{array}{c}\mathrm{P} \\
\mathrm{ppm}\end{array}$ & $\begin{array}{c}\mathrm{Zn} \\
\mathrm{ppm}\end{array}$ & $\begin{array}{c}\mathrm{Cu} \\
\mathrm{ppm}\end{array}$ \\
\hline Satkhira & $6.2-8.4$ & $1.8-2.2$ & $0.9-0.3$ & $14.2-25.5$ & $0.5-0.6$ & $0.2-1.2$ & $6.3-16.2$ & $2.8-11.4$ & $12-24$ & $0.1-0.8$ & $0.08-0.30$ \\
\hline Khulna & $6.2-7.9$ & $0.1-0.3$ & $0.1-0.3$ & $18.2-40.6$ & $1.6-33.3$ & $0.3-1.0$ & $8.3-22.5$ & $2.6-18.3$ & $8-36$ & $\mathrm{Tr}-0.8$ & $\operatorname{Tr}-0.20$ \\
\hline Bagerhat & $6.0-7.8$ & $0.3-2.8$ & $0.1-0.2$ & $15.9-37.0$ & $0.6-7.0$ & $0.2-1.0$ & $9.4-24.2$ & $4.2-17.7$ & $6-26$ & $\operatorname{Tr}-1.6$ & $\operatorname{Tr}-0.40$ \\
\hline Patuakhali & $5.0-7.8$ & $0.1-1.0$ & - & - & - & $0.2-0.6$ & $2.7-7.5$ & $1.6-6.6$ & $10-28$ & $0.2-0.8$ & $0.06-0.39$ \\
\hline Barguna & $6.3-8.0$ & $1.2-2.3$ & $0.1-0.1$ & $12.0-22.0$ & $2.5-21.7$ & $0.2-0.7$ & $11.5-28.8$ & $3.9-18.2$ & $4-14$ & $\operatorname{Tr}-3.0$ & - \\
\hline Bhola & $6.3-8.0$ & $0.4-7.1$ & $0.1-0.2$ & $11.8-26.0$ & $0.6-3.4$ & $0.1-0.4$ & $7.2-20.8$ & $2.0-9.5$ & $8-30$ & $\operatorname{Tr}-1.4$ & $\operatorname{Tr}-0.70$ \\
\hline Chittagong & $5.0-7.4$ & $1.0-2.9$ & - & - & - & $0.2-0.8$ & $2.7-7.1$ & $2.9-11.3$ & $4-11$ & $0.1-0.9$ & $0.3-1.0$ \\
\hline Noakhali & $6.0-7.9$ & $0.8-3.1$ & $0.1-0.3$ & $9.4-19.5$ & $0.4-39.0$ & $0.1-0.5$ & $5.3-12.4$ & $2.3-9.5$ & $8-24$ & Tr-1.8 & Tr-0.70 \\
\hline Feni & $6.0-7.5$ & $0.9-2.9$ & $0.1-0.2$ & $11.8-16.2$ & $0.8-3.8$ & $0.4-0.5$ & $7.8-8.0$ & $5.0-6.8$ & $8-24$ & 0.9 & - \\
\hline
\end{tabular}

Sources: Annual reports of BARI, BRRI, BWDB and DU of Bangladesh (1987-1989).

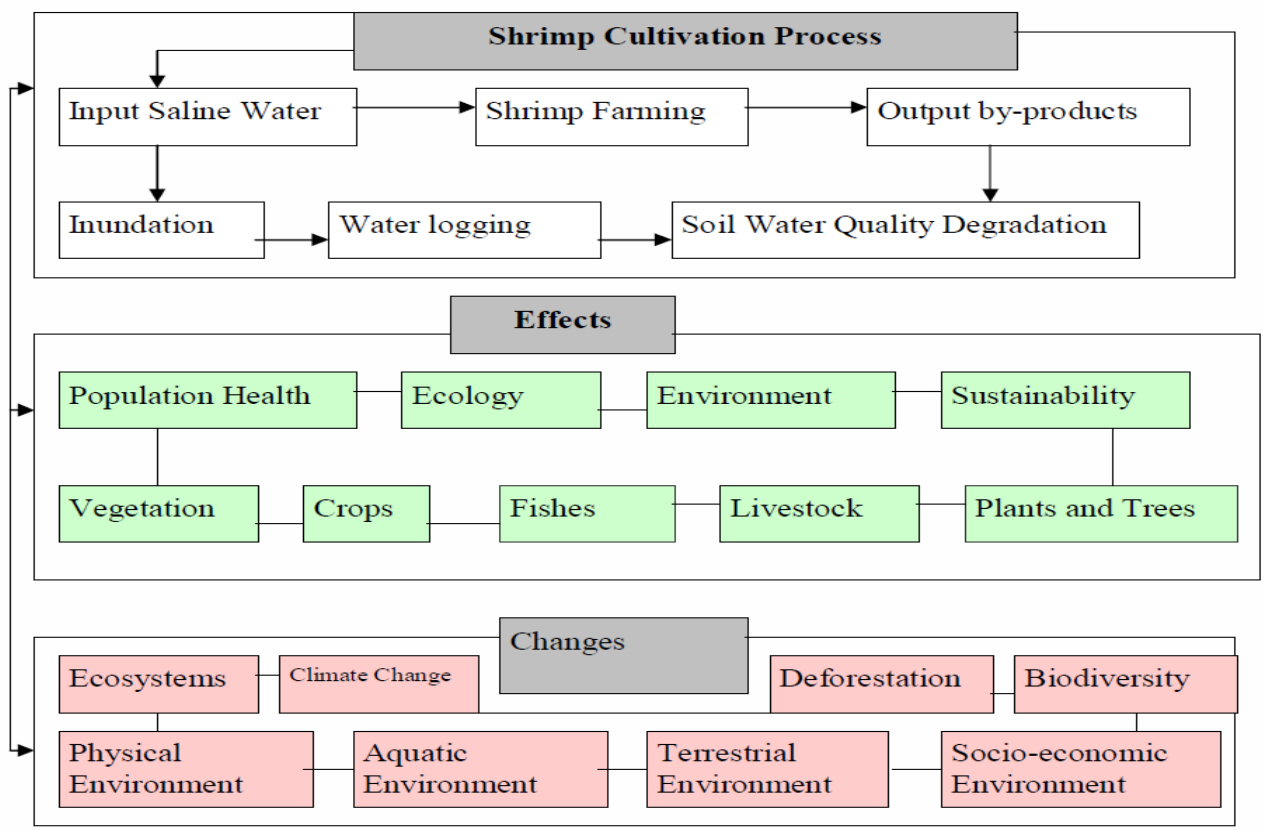

Source: (Karim 2006)

Figure 5. Diagrammatic Model of Shrimp Cultivation Process, Concomitant Effects and Changes due to Shrimp Farming 


\subsubsection{Impact on Soil and Agriculture}

Shrimp farming affects soil and water quality in the cultivated areas that increase soil salinity levels (up to 500\%) in non-saline area that hampers crop cultivation seriously [19]. Peasant households loose their income due to decline in rice productivity, loss of poultry and livestock, and erosion of homestead vegetation and social forestry $[5,20]$.

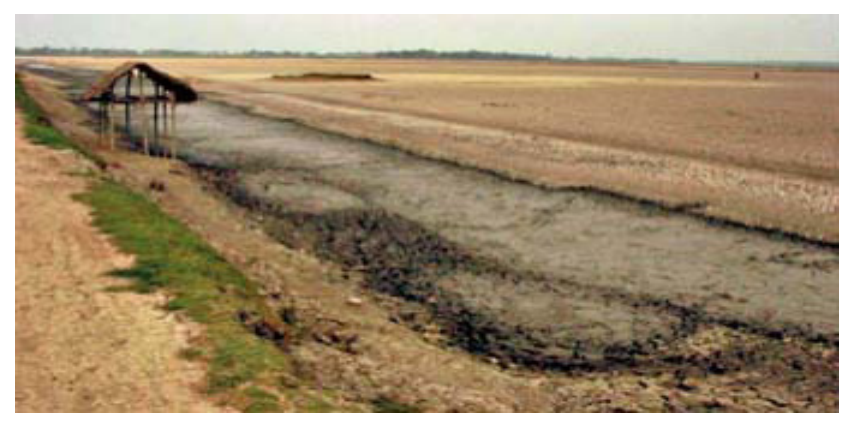

Figure 6. Intrusion of Water Salinity in Fresh Land and Its Impact on Agriculture

A scientific study sponsored by Nijera Kori (1996) found increase salinity and soil degradation and vegetation loss in the coastal regions. Cultivation of shrimp needs storage of saline water for a long period of the year. Vast areas of cultivable land in the coastal areas where once paddy was grown were turned into shrimp farms. It paid off instantly. But after about ten years of harvesting, these shrimp farms were crashed because of virus infection. Pathogens settled into the muck of shrimp waste and unconsumed fodder, poisoning a pond against further use. The irony is that even when the water releases, salt spills out in the surface land and vast areas become unfit for any type of cultivation [21]. As the shrimp growers cannot use a pond over and over again, so they are to shift the cultivation to somewhere in surrounding area. A picture of Figure- 6 shows the process how shrimp culture occupies the agriculture land fast. Because of changes in culture practices, saline water is retained for long time which virtually leads to percolation of salts in surrounding soil resulting in changes in soil chemistry. When monsoon rainfall comes early and rains heavily, the shrimp producers keep on adding extra salt into the water to ensure better growth of shrimp. The extra salt eventually gets stored in the field and adds to the level of soil salinity further. This process hampers the microbiological system and decreases the soil fertility significantly [1]. The primary adverse effect of excessive salinity is to raise the concentration of soil solution, as a result of which the flow of water into the plant by osmosis is reduced or reversed, the plants starve of water, and even the soil is moist and creates physiological drought conditions and consequently goes died $[21,22,23]$.

\subsubsection{Impact on Livestock and Public Health}

A study of CARE International in 1999 shows average number of cow per household (1.6) decreased significantly. In 1980, data shows 81.7\% households had cows but in 1999 only $49.3 \%$ households had cows. Average number of poultry per household was 3.8 nos. in 1980 that increased to 5.2 nos. in 1999. Average number of goat per household was 3.3 nos. in 1980 but in 1999 it decreased at 1.3 nos. Livestock also decreases due to loss of common resources for grazing. The rate of decreasing grazing land is $64 \%$ over last twenty years. The reasons of decreasing grazing lands are shrimp culture expansion. Low lying land where people used to grow only one crop in a year was previously used as common grazing land for much of the year. As a result, the number of cattle and goats is decreasing. Whereas number of ducks has increased because households prefers domesticate ducks as it is easy to get enough shrimp ponds for rearing of ducks $[1,22]$.

The extent of salinity in groundwater is also increasing because of continuous shrimp cultivation in the fresh agricultural land. Use of tube wells in coastal areas is not common, and most people use pond water or rainwater in the monsoon season. But in the dry season, it is difficult to procure potable water and they need to walk considerable distances to procure water from freshwater ponds [24]. Water concerns are also differentiated by social class in coastal areas. Richer households can generally create and maintain fresh water ponds for consumption. Poorer people, by contrast, may have to walk 2 to $5 \mathrm{~km}$ to get drinking water, or provide free labor in return for access to closer water sources. Besides, poor people now spend most of the day in rivers and creeks to collect shrimp fry often standing in waist-deep water which increases health problems (e.g., skin diseases) [22, 25]. A decline in nutritional diversity is suspected as consumption of fish, poultry, fruits, and vegetables declines from falling survival rates of different species of plants and animals due to increased salinity. Such realities adversely impact population health, nutrition, workload, and livelihood strategies. Thus, diseases and pollution because of this cultivation may limit a farm's life to 10 years [21]. The most unexpected consequence of the transformation of traditional agriculture into shrimp cultivation is rural-urban migration. The shrimp industry reduces the on-farm work opportunities considerably for marginal and landless farmers. As a result, a section of rural people looses employment, and these rural unemployed laborers usually migrate to cities for seeking work $[1,24]$.

\subsubsection{Impact on Coastal Bio-Diversity}

In Bangladesh, hatchery production remains quite limited and fulfils around $17 \%$ of the demand of Post Larva per year. Moreover, farmers prefer wild PL because of their hardy characteristics. Survival of wild PL is higher than hatchery PL as they hatch and grow up in natural conditions. Fishermen use nets or very fine mesh to capture shrimp fry from wild stock. The polluted wastewater is generally pumped back into the surrounding environment in order to save costs. Moreover, the fishermen are especially interested to catch the shrimp post larva and collect fry of different species as 'by-catch' from the river. During collection of a single shrimp PL on average 1,341 fries of different species 
were caught in 1998, 2,038 fries in 1999, and 1,611 fries in 2000 [26]. Thus, natural catch of fish decreased $90 \%$ over last 20 years and a declining catch of wild shrimp post larvae reports to be decreased in Bangladesh [27] because of overfishing of post larvae. Shrimp farmers apply different types of chemicals/medicine to save their ponds from oxygen deficiency and subsequent diseases. The farmers are not aware of the impact of the use of these chemicals on pond environment. The survey conducted by CARE International shows that about $21 \%$ farmers used Potassium permanganate, $18 \%$ used Aqua-nourish, $17 \%$ used Capsule and 14\% Agro-fish and almost all chemicals were used mainly for improving water quality and preventing diseases. Overuse of the chemical might be the cause of killing of many living organisms [5, 24].

Shrimp farming rely heavily on compound aqua feeds made largely from fishmeal, because they mimic the composition of the natural food of carnivorous fish and crustaceans as the simplest means of providing the nutritional requirements needed by these species on a daily basis. Shrimp farmers have traditionally used the meat from the freshwater Apple Snail as a feed for the prawns. As shrimp farming became more popular, the demand for snail meat grew and the harvest of snails intensified so much so that they disappeared from many local wetlands. The estimated annual harvest of P. Globosa from various Beel, Canals, and rice fields in 1999 was 365,849 Metric Tons [28]. P. Globosa plays an important role in the wetland ecosystem occupying an intermediate role in the food chain consuming photo-plankton, algae, aquatic plants and insects. The eggs are a potential feed for fish, snakes, ducks, rats and birds. The recycling of alkaline elements found in the shell of the snail could also be important in maintaining water and soil chemistry. The long-term effects of these species removal on the ecological balance of the wetlands are unknown $[1,24]$.

The wetlands are the natural breeding grounds for native/wild fish and support a wide range of wetland flora and fauna. During the shrimp revolution, the low-lying land in the wetlands was highly sought as it was easily converted into rain fed ponds that could retain water throughout the year. Most of the wetlands and many of the canals are the "lifelines" through which fish migrate to and from Bangladesh's main river systems are now congested with shrimp ponds. The poor drainage and reduced flow cause many canals to completely silt-up. Destruction of their natural feeding and breeding grounds leads to sharp declines of native fishes. Due to salinity many fresh water fish species like Ruhi, Katla, Shole, Boal, Tengra, Koi, Shing etc. are about to disappear in the localities. The long term inundation has also destroyed the traditional fishes. Along with the likely decline in fish populations and diversity, many other species of flora and fauna have disappeared from these wetland areas in the coastal regions [29].

Water bodies are contaminated with high salinity that does not favor growth of many fresh water organisms. The higher concentration of salts in soil also affects adversely the ammonifiers and decreases the number of denitrifying, microorganisms [19]. Nitrification shows variances with the nature of the salt and with the level salinity. The population of Azotobacter differs on various salt concentrations. The number of fungi colonies decreases with increasing salinity of the soil. When the solute in water increase in concentration, cellular dehydration commences ultimately and causes the death of the organisms. Many shrimp farmers very often kill mammals and reptiles considering them harmful for the shrimp and sharer with the foods of shrimp. Many of those animals are almost abolished from shrimp producing localities [20, 24].

\subsubsection{Impact on Ecology}

The process of shrimp farming in south-western districts started two decades ago is destroying natural environment, ecosystems and social systems [20,30]. High rates of destruction of mangroves and occupying of wetlands for shrimp industry happen in Bangladesh. As shrimp ponds maintain intensive yields and high returns, and the wholesale conversion of surrounding land areas is required, aquaculture production of shrimp becomes the most relentless destroyer of large areas of pristine tropical wetlands. Mangrove forests, the most notable ecosystems, fall under the prey of shrimp pond construction with its massive destruction. A number of shrimp ponds developed along the periphery for catching shrimp fry shrinks the reserve area of the mangrove forest 'Sundarban'. The extreme fishing pressure grasps shrimp fries as well as other important revering species that spawn in the coastal areas. It destroys the environment of the coastal area ecosystems as well [1].

Mangrove trees are common in all over the coastal areas of Bangladesh apart from the Sundarban forest. As presented by Figure-7, the pond construction for shrimp farming eradicates natural mangrove vegetation; the construction of canals and dikes alters irreversibly the hydrological characteristics of the coastal areas. Whenever a pond exhausts its usefulness usually within three to six years, farmers move along the coastal mangroves and rice fields to make room for more ponds [5]. Thus, unplanned shrimp farms lessen productions of paddy, rabi crops, vegetables and other agro-products significantly. Increase of salt sedimentation on soil and its erosion, decrease in soil fertility, livestock and organic manure negatively affect on the process of crops yield. Simultaneously, it harms not only the soil and ecology but also pollutes the environment in and around the Sundarbans and its ecosystems [1]. 


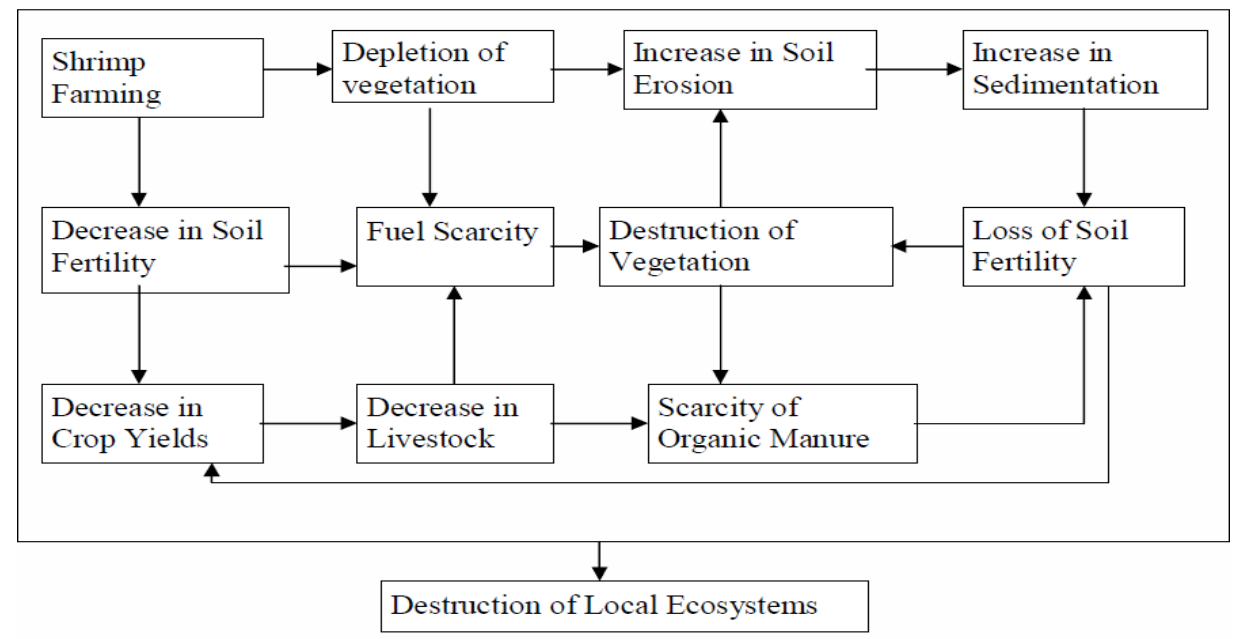

Source: (Karim 2006)

Figure 7. Effects of Shrimp Farming on Local Eco-systems

\subsubsection{Impact on Environment}

Bangladesh is experiencing many natural catastrophes like cyclone, tidal weaves almost in every year because of increasing warming due to deforestation, destruction of mangrove forest, weakened coastal defense and the like. Industrial shrimp farming has been a major cause of the destruction of mangrove wetlands and bio-diversity which has also led to loss of protection regarding cyclones. Deforestation has left the area highly vulnerable to decreased coastal defense and sea water intrusion when cyclones strike. Thus, shrimp cultivation compounds environmental insecurity. A research carried out by India's University of Delhi and Duke University in the United States studied storm-related deaths from the massive cyclone that in 1999 villages shielded from the storm surge by mangrove forests experienced significantly fewer deaths. The research findings were made public in April this year, just a month before cyclone Aila killed more than 90 people in the south-western districts of Bangladesh and flooded about $40 \%$ of the shrimp farms in the Khulna region in May 26 in 2009. Tragically, replacing mangroves by cash earning shrimp production has now led people into bankruptcy and left them with no protection or food [22, 31, 32].

\subsubsection{Impact on Sustainability}

Shrimp cultivation is directly affecting the sustainability of the southern coastal regions in Bangladesh by causing multiple problems in different ways. In case of sustainability, the following problems are resulted from 'unplanned' shrimp cultivation [33]:

1. Lower production from paddies;

2. Destruction of trees and vegetation due to salinity;

3. Decline in household incomes from non-farm sources especially those from ecological reserves;

4. Decline in the production of poultry and live stock;

5. Various forms of social conflicts and tensions;

6. Using farm-level data on shrimp cultivators, landowners and landless laborers in the coastal districts of Bangladesh, the following broad findings have been reported as a question of sustainability [34]:

7. Uneven gains between shrimp producers and landowners especially in the small-owing households;

8. Adverse environmental spill-over in the form of loss of green vegetations, loss or extinction of indigenous species of fishes and declining rice yields;

9. Increased employment opportunities off the shrimp farms i.e. an overall decrease in employment;

10. Depending on the contractual arrangements with the financiers, some 'Gher' owners also stand to lose from environmental degradation;

11. Shrimp farming on a large scale in the coastal regions of Bangladesh has created a new employment structure for a specific portion of people.

Although shrimp farming itself is less labor-intensive than rice cultivation [5], in reality the situation does not exactly follow the assumption, since outside shrimp producers prefer hiring laborers from outside $[16,35,36]$.

\section{Discussion}

Shrimp cultivation is now widely spread almost all over the coastal regions of Bangladesh. Different species of shrimps are cultivated generally in low lying, barely one meter above mean sea level and below high tide level areas where nutritious and organic foods are available for all types of aquatic lives. The people who live in and around the farm lands are not able to control its rapid expansion, stop or reduce farms, and protect the aftermaths of unplanned cultivation as the rich people own most of it. Long time farming has already emerged as a great threat to the agriculture, livestock, biodiversity, public health, ecology, local environment and sustainability in the coastal regions of Bangladesh. 


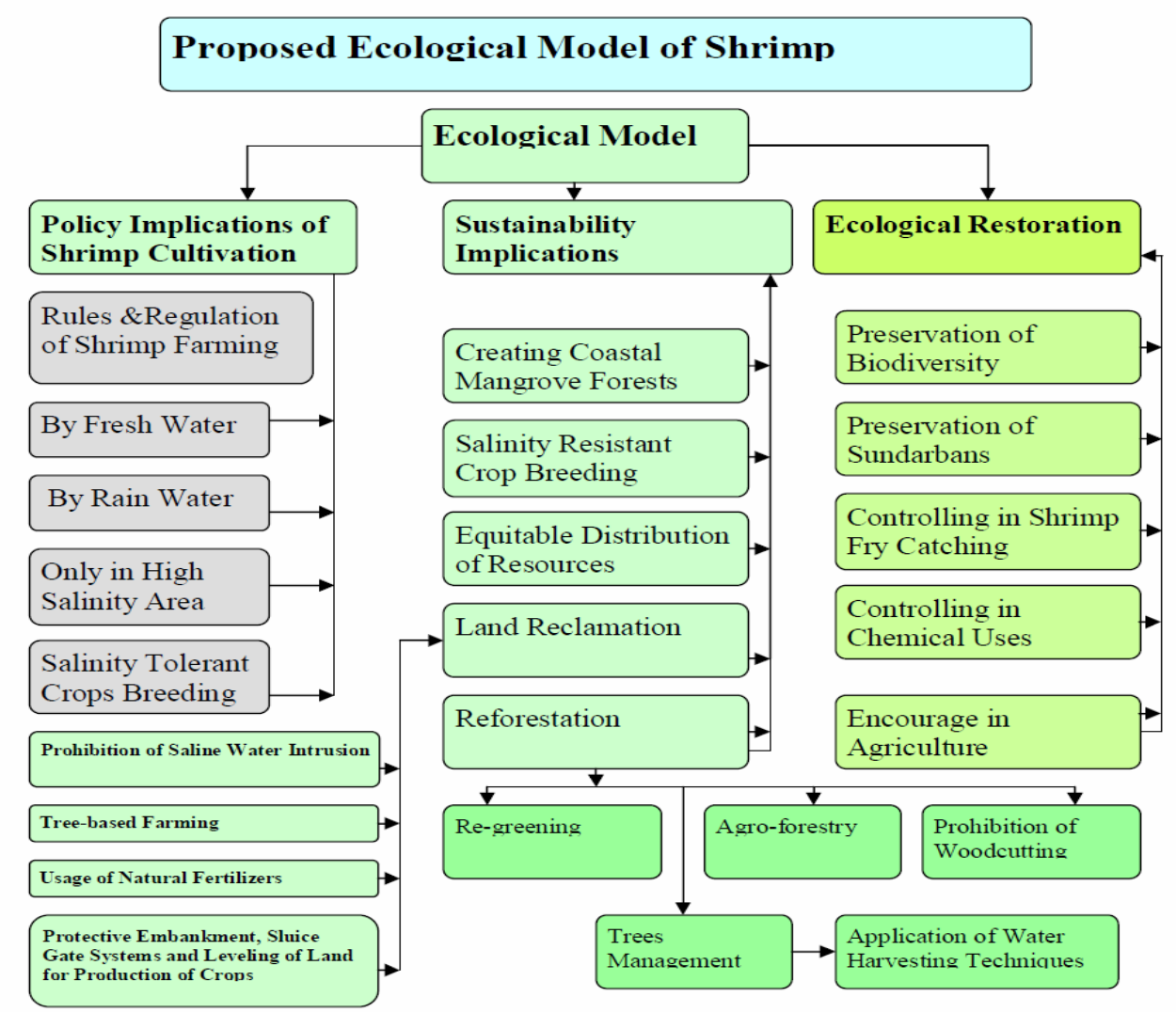

Source: Proposed Techniques of Ecological Model [1, 5, 37]

Figure 8. A Proposed Ecological Model for Encountering Adverse Effects of Unplanned Shrimp Cultivation in Bangladesh

The government defies the adverse effects of shrimp industry as it earns foreign currency to a great deal and adds to its weakened economy every year. Most of the economically solvent and politically powerful persons are acculturate with the process of shrimp production. They tend to earn money defying of the long term adverse effects of the shrimp farms on the local environments and its inhabitants. Since, shrimp industry is meanwhile expanded along with the coastal regions and many types of influential persons are engaged with it, there is 'no-regret' option but to diminish the inclusive adverse effects of shrimp industry in Bangladesh. In these circumstances, the policy implication of the government and its proper implementation, proposed techniques of the ecological model of shrimp farming stated by Figure- 8 likely regain the fertility of the lands occupied by land gravers for shrimp faming with water salinity, revitalize the process of ecological restoration, and reduce the risks of destroying local livestock, biodiversity, ecosystems, environment and sustainability.

1. A coastal saline soil occupies the river deltas and the landscapes are generally low-lying, estuaries and inland along the seacoast of Bangladesh. According to salinity survey findings and salinity monitoring information, about 1.02 million hectors (about $70 \%$ ) of the cultivated lands are affected by varying degrees of soil salinity. Land reclamation and cropping intensity may be increased by using the techniques of stop or control of saline water intrusion by shrimp farming, the usage of natural fertilizers, agro-forestry, tree-based farming and water management practices with introduction of salt tolerant varieties of different crops. To mitigate the demand of fresh water for irrigation, especial emphasis may be given to adopt rain water harvest technology.

2. Since few years ago, a trend has been started to cultivate saline water shrimp in fresh water pond. This process is still at experiment stage. This way of shrimp cultivation, if possible in sustainable manner, could reduce the adverse effect of existing shrimp cultivation. So, initiatives like prohibition of shrimp cultivation, shrimp cultivation by fresh and rain water, and only in high salinity areas should be taken for sustainability.

3. As a world heritage, the Mangrove forest 'Sundarban' must be protected from the prey of shrimp fry collectors and shrimp cultivators. Efforts to protect the mangrove forests and local fishes must be strengthened. The concerned policy makers should learn a lesson from China that now prohibits converting arable land into aquaculture ponds. India has already banned farms within 500 meters of its high-tide zone.

4. To establish the procedures for Environmental Impact Assessment and monitoring that could minimize the adverse ecological changes and related social and economic consequences resulting from shrimp culture with water salinity, land use, discharge of effluents, use of drugs and chemicals. 
5. In 1960s, when the 'Theory of Green Revolution' was propounded in the face of steadily increasing population and the shortage of sufficient food grains to feed them. The whole world was mobilized under the slogan 'Grow More Food' with the assistance of USAID that considerably enhanced agricultural production in this region. So, the initiatives of 'Green Revolution' through reforestation by agro-based farming, trees nursing and management, prohibition of wood cutting [37] and 'Grow More Food' through rain water could strengthen the ecological restoration in the coastal area.

6 . The steps to improve land use planning and identify appropriate areas for shrimp cultivation needs to be prioritized. Saline water shrimp cultivation must be restricted for land reclamation and encouraged only where the soil salinity level is high.

7. To improve environmental balance through making coastal mangrove forests so that natural catastrophes like cyclone, tidal weaves, and thereafter intrusions of saline water can be controlled by coastal defense.

8. The shrimp fry catching needs to be regulated. Fry catching should be banned in certain ecologically sensitive areas e.g. the surroundings of Sundarban and migration routes where adequate hatcheries exist.

9. A seasonal ban should be applied during the fish breeding season from August to January because there is no PL requirement during the rainy season and stocking PL during the winter months.

10. Shrimp fry catching by using fine meshed nets should be banned or at least regulated through licensing system. Mesh sizes for other nets should also be regulated.

11. The movement of subsistence fishing and farming can make a profound implication to the step of food and livelihood security of the poor people. Like the 'Green Revolution', the 'Blue Revolution' through equitable distribution of resources should be strengthened for the people who are victimized by water salinity, who have no land to grow food or no money to buy food.

12. Research should be conducted to find out appropriate alternatives (including the proposed ways) for land reclamation with a view to use it for agriculture in future. Research should be conducted to find out an appropriate solution for post drainage management and the salted or waste water form removal from shrimp ponds.

13. Land may be protected from inundation of saline water through establishment of embankment. Provision of sluice gate in the embankment system needs to remove excess water and also to prevent ingress of saline water during high tide. Land should be properly leveled to prevent accumulation of water in the low-lying patches and to facilitate uniform drainage in removing excess water. It will help to apply irrigation water uniformly in the field, and facilitate uniform germination of seeds and better growth of crops.

\section{Conclusion}

Unplanned Shrimp cultivation has multifarious impact in terms of salinity increase on soil, adverse effects on population health, destroying bio-diversity and ecosystems, environmental changes, and imbalance in sustainability. In spite of the negative impacts, the economic importance of shrimp cannot be overlooked for a developing country like Bangladesh. Proper management and planning by framing an 'Ecological Model' can give a sustainable growth and benefit of shrimp cultivation, stop the trends of water pollution and destruction of sensitive coastal habitats, lessen the ongoing threats to aquatic biodiversity, and balance the significant socio-economic costs against the direct economic benefits or earning from the shrimp cultivation. Apart from the implications of the proposed ecological model, the steps should be adopted for accrediting the need of future achievements by shrimp farming in Bangladesh:

Granting a certification of sustainability (concerning ecological, economic and social factors) for the shrimp cultivation farms where a correct planning had been realized;

Sensitizing the leading importers in order to encourage shrimp importation exclusively from certified farms; advising leading food brands to publicize the exclusively usage of shrimps from certified farms in their merchandise;

Educating customers in order to influence consumer's behavior towards assumption of shrimps from certified farms;

Alerting international organizations in order to launch protection programs in the critical geographic areas.

\section{Acknowledgements}

We would like to thank Vaiva Šečkute for her help in editing the manuscript.

\section{REFERENCES}

[1] Anwar, Syed Mahmood. Effect of Shrimp Culture on Ecology in the Coastal Areas of Bangladesh. Human Landscape Ecology, (MNFEL 330), 2003 Retrieved on May 10, 2013 from

http://www.sma-bd.com/documents/Effect\%20of\%20Shrimp $\% 20$ culture.PDF

[2] Primavera J. H. Socio-economic Impacts of Shrimp Culture in Aquaculture Research, South-East Asian Fisheries Development Centre, Vol. 28, Ilolio, Philippines, pp. 815-827, 1997.

[3] Acqua International. Acqua International, Ahasan Ahamed Road, Khulna, Bangladesh. 2012. Online available from http://acqua-int.com/

[4] The Independent. Shrimp Farming: Ecological Impact has to 
be assessed, Newspaper Article, The Daily Independent, Dhaka, Bangladesh, 2002.

[5] Haque, S. A. Salinity Problems and Crop Production in Coastal Regions of Bangladesh, Pakistan J0urnal of Botany, 38(5): 1359-1365, 2006. Retrieved on May 092013 from http://www.pakbs.org/pjbot/PDFs/38(5)/PJB38(5)1359.pdf

[6] DDP (Delta Development Project). Shrimp culture in the semi-saline zone of the Delta: final report. Technical Report No. 13, Bangladesh-Netherlands Joint Programme. The Hague, Delta Development Project, 1985.

[7] Karim, M. Brackish Water Shrimp Culture Demonstration in Bangladesh", Development of Small-Scale Fisheries in the Bay of Bengal, Bay of Bengal Programme, Madras, India. Executed Agency: FAO (Food and Agriculture Organization of the United Nations), 1986. Online available from $\mathrm{ftp}: / / \mathrm{ftp}$.fao.org/

[8] Haque, S.M. Annual report of Bangladesh Frozen Foods Exporters Associations (BFFEA), BFFEA Special Bulletin, Dhaka, Bangladesh, 1994

[9] MPO (Master Plant Organisation). Final Report, Volumes I-III, Master Plan Organisation. Dhaka, Bangladesh.Nijera Kori (1996). The Impact of Shrimp Cultivation on Soils and Environment in Paikgacha Region, Nijera Kori, Khulna (Limited to Polders 20, 21, 22, 23 and 24), Khulna, Bangladesh,1986.

[10] DOF (Department of Fisheries). District-wise Area and Number of Shrimp Farms. Dhaka, Department of Fisheries Document, 1994.

[11] Rosenberry, B. World Shrimp Farming 1995, Annual Report, Shrimp News International, San Diego, 1995.

[12] MPO (Master Plan Organisation).. Coastal Shrimp Aquaculture Resources, Technical Report No. 18, 1987. Master Plan Organisation. Dhaka, Bangladesh.

[13] Rosenberry, R.. World Shrimp Farming 1995, Shrimp News International, San Diego, CA.

[14] ESCAP (Economic and Social Commission for Asia and the Pacific). Coastal Environmental Management Plan for Bangladesh, Final Report, Volume II, United Nations Economic and Social Commission for Asia and the Pacific, Bangkok, Thailand. 1988.

[15] Kashem, A. Chingri Chashe Biplabattak Utpadan abang Raptani Aye, The Ittefaq, 25 February 1996, Dhaka, Bangladesh.

[16] Datta, Dilip Kumar., Roy, Kushal and Hassan, Nazia. Shrimp Culture: Trend, Consequences and Sustainability in the South-western Coastal Region of Bangladesh Management and Sustainable Development of Coastal Zone Environments, Springer Link, pp 227-244, 2010.

[17] Khan, A.N.M.S.H. Shrimp Report on Bangladesh. In: Rosenberry, B. World Shrimp Farming 1995, Annual Report, Shrimp News International, San Diego.

[18] Begum, A., and S.M.N. Alam. Social and economic impacts of shrimp disease among small-scale, coastal farmers and communities in Bangladesh. p. 191-200, 2002. Online available from http://www.fao.org/

[19] Islam M.A., Sattar M.A. and Alam M.S. Impact of Shrimp
Farming on Soil and Water Quality of Some Selected Areas in the Greater Khulna District, Research and Development Collective, Dhaka, Bangladesh, 1998.

[20] Manju, T. Political Economy of Shrimp Culture in Bangladesh, Poverty Research Report 13, 1996. Report prepared for the Grameen Trust, Grameen Trust, Grameen Bank, Dhaka.

[21] Hagler, M . Shrimp: The Devastating Delicacy, Green Peace Report, Greenpeace USA,1997.

[22] Ghafur A, Kamal, M. Dhaly MR, Khatun S. Socio-Economic and Environmental Impact of Shrimp Culture in South-western Bangladesh: An Integrated Approach, Nijera Kori and IDPAA at Proshika, Dhaka, Bangladesh,1999.

[23] Karim, Md. Rezaul. 5 Brackish-water Shrimp Cultivation Threatens Permanent Damage to Coastal Agriculture in Bangladesh, Urban and Rural Planning Discipline, Khulna University, Khulna, Bangladesh, CAB International 2006, Environment and Livelihoods in Tropical Coastal Zones (eds C.T. Hoanh, T.P. Tuong, J.W. Gowing and B. Hardy).

[24] Hagler, M., Gianni, M. and Cardenal, Lorenzo . Shrimp: The Devastating Delicacy: The Explosion of Shrimp Farming and the Negative Impacts on People and the Environment, Greenpeace report, Publisher: Greenpeace USA, University of California, USA, 2009.

[25] Datta, Anjan. Who benefits and at What costs? Expanded Shrimp Culture in Bangladesh, Institute of Social Studies, Publisher: Institute of Social Studies, 1995.

[26] Toufique, K.A. Impact of Structural Adjustment Policies on the Environment in Bangladesh, Bangladesh Institute of Development Studies (BIDS), Dhaka, 2002.

[27] Islam, S. Impact of Gher Farming on Agriculture and Livestock, a Study report, CARE Bangladesh, GOLDA Project, Dhaka, Bangladesh, 1999.

[28] CARE Int'1., 1999. Environmental Impacts of Gher Farming. Online available from http://www.careinternational.org.uk/

[29] Datta, A. Who Benefits and at What Costs? Expanded Shrimp Culture in Bangladesh, Grassroots Voice: A Journal of Indigenous Knowledge and Development, Vol. III, Issue, IV, Dhaka, Bangladesh, 2001.

[30] Deb A. K.. Fake Blue Revolution: Environmental and Socio-Economic Impact of Shrimp Culture in the Coastal Areas of Bangladesh, Community Development Centre (CDC), Canada, 1997.

[31] Kabir, A. K. M Enayet. Shrimp Farming: Ecological impact has to be assessed. The Independent, The Independent (Bangladesh), Dhaka, Bangladesh. 2002.

[32] Azad, Rafiqul Islam. Climate Change Impact: Unplanned Shrimp Cultivation threatens Environment, 2009. Online available from http://nation.ittefaq.com/

[33] Rahman, A., Islam, M.A., Roy, I., Azad, L. and Islam, K.S. Shrimp Culture and the Environment in the Coastal Region, Bangladesh Institute of Development Studies (BIDS), Dhaka, Bangladesh, 1995.

[34] Alauddin, M. and Tisdell, C.A.. Bangladesh's shrimp industry and sustainable development: resource-use conflict and the environment. Working Paper No. 1, Shrimp-Rice 
Farming Systems in Bangladesh Working Paper Series. Brisbane, Department of Economics, University of Queensland, Australia, 1996.

[35] Bhattacharya D., Rahman M., Khatun F.A. Environmental Impact of Trade Liberalization and Policies for the Sustainable Management of Natural Resources: A Case Study on Bangladesh's Shrimp Farming Industry, Centre for Policy
Dialogue (CPD), Dhaka, Bangladesh, 1999.

[36] WCED (World Commission of Environment and Development). Our Common Future Oxford, Oxford University Press, UK, 1987.

[37] Giono, Jean. The Man Who Planted Trees, 1953. Unabridged by Michael McCurdy and Norma L. Goodrich. Shambhala

Publication, Inc., Boston, USA,

1999. 